Article

\title{
Is Foreign Aid Responsive to Environmental Needs and Performance of Developing Countries? Case Study of the Czech Republic
}

\author{
Zdeněk Opršal *(i) and Jaromír Harmáček \\ Department of Development and Environmental Studies, Palacký University Olomouc, 77146 Olomouc, \\ Czech Republic; jaromir.harmacek@upol.com \\ * Correspondence: zdenek.oprsal@upol.cz; Tel.: +420-585-634-984
}

Received: 10 December 2018; Accepted: 9 January 2019; Published: 14 January 2019

check for updates

\begin{abstract}
This paper examines the responsiveness of foreign aid to environmental needs and performance of developing countries using, as an example, the Czech Republic. It focuses on the environmental component of foreign aid, which is defined as the development intervention of the Czech Government, which can be expected to have positive environmental impacts in target countries. The provision of environmental aid is based on the assumption that the Czech Republic has practical, transferable experience of qualitative improvements in the environment following the collapse of communist regime. Flows of environmental aid were determined by analyzing and categorizing individual development aid projects in the period 2000 to 2015. Regression analyses were employed to explain the pattern of Czech environmental aid allocations. The results show relatively limited reflection of the recipient's environmental needs in the distribution of Czech environmental aid. Only two environmental objectives were significantly echoed in actual aid flows. The first was transfer of advanced environmental technologies and reductions in energy consumption, approximated by carbon dioxide emissions per capita. The second was protection of biodiversity, represented by the extinction risk of sets of species. The other five objectives did not play significant roles in environmental aid allocations. Above that, other factors not related to the environmental needs and performance of recipient countries affected Czech environmental aid. Among them, historical ties to other former communist countries were of high significance. The findings call into question the environmental objectives of Czech foreign aid and point to the need for transparent criteria for the allocation of environmental aid.
\end{abstract}

Keywords: environmental aid; foreign aid; sustainable development; environmental indicator; Czech Republic

\section{Introduction}

The Czech Republic is a post-communist country that has undergone a period of significant economic, political, and environmental changes after the collapse of the communist regime. In the field of the environment, the Czech Republic had to deal with serious environmental burdens resulting from the neglect of the environment by the communist regime prior to 1989 [1-3]. Emphasis on the development of heavy and extractive industries and the intensification of agriculture under the Soviet economic model have left a negative legacy in the high levels of air pollution, water pollution, and soil degradation $[4,5]$. The gradual improvement of the situation can be attributed partly to the industrial decline and the subsequent restructuring of industry in the 1990s [5,6] and partly to the introduction of new legislation and environmental standards [7]. The gradual strengthening of environmental legislation and standards was part of the effort to demonstrate a readiness to join 
Western organizations [3,5]. The process resulted in the decreasing of energy and material demands of the Czech economy and a greater use of cleaner energy sources, a reduction in total emissions of all major air pollutants (excluding greenhouse gases), and a reduction in pollution of watercourses $[6,8]$. Although some environmental problems persist [5], the experience gained in the implementation of environmental policies and technological innovations is recognized by the international community [9] and Czech government [10] as valuable and unique, even in the international context.

By coincidence, the process of environmental transformation in the Czech Republic took place in the same decade when the concept of sustainable development gained international attention. The concept was derived from the 1987 Bruntland report and it received international attention at the United Nations Conference on Environment and Development (also known as the Earth Summit) held in Rio de Janeiro in 1992 [11]. The debate on environmental sustainability has influenced not only international environmental concerns, but also external aid funding for environmental purposes [12,13]. The demonstration of the gradual environmentalization of the international development agenda are the Sustainable Development Goals adopted at the UN Sustainable Development Summit in 2015 [14]. The environmental component has been strengthened not only within the framework of the international development agenda, but also at the level of development strategies of individual donors. This reflected a growing consensus that the environment and development are interlinked $[15,16]$. Although the environment-poverty relationship is complex and should not be simplified as a "vicious cycle" [17,18], environmental degradation may undermine development prospects $[19,20]$. Environmental considerations have become a "cross-cutting principle" (along with good governance and gender sensitivity) of donor development interventions and the term "sustainable development" has turned into a buzzword within the international development community [11].

Both the domestic environmental transformation and international environmentalization of development agenda paved the way for Czech environmental aid. The Czech development aid program was restored in 1996 in connection with the Czech Republic's accession to the Organization for Economic Cooperation and Development (OECD) [21]. The restoration of development aid was primarily a political signal and part of the effort to become part of Western political and economic structures [22]. The first reference to the environmental dimension of the Czech Republic's development assistance program appeared in the strategy paper "Development Cooperation Strategy for 2002-2007" adopted by the Czech government in 2002 [23]. The strategy placed "the promotion of sustainable development with an emphasis on its environmental component" [23](p. 3) among the three main objectives. The strategy also referred to the EU and OECD recommendations to use the comparative advantage in the form environmental expertise from a transition period. The second strategy, entitled "Development Cooperation Strategy of the Czech Republic 2010-2017" [24], was even more specific in relation to the environmental aspect of development. The strategy introduced environmental sensitivity as one of cross-cutting principles for Czech development cooperation. It stressed that "the Czech Republic has practical, transferable experience of qualitative improvements in the environment and of the introduction and implementation of environmental law and policy" [24](p. 17).

For what reason are donors increasingly engaged in environmental aid transfers? The foreign aid literature hypothesizes that if donors are genuinely motivated by humanitarian concerns, they will allocate aid among recipients on the basis of relative needs, allocating most aid to countries with a low level of development, a high level of poverty and so on $[25,26]$. When the "needs" hypothesis is applied to the environmental concerns, then donors should prioritize developing countries with higher environmental needs such as a high concentration of endangered species, high deforestation rate, or insufficient access to safe drinking water. In addition to the environmental needs of developing countries, donors can also take into account their environmental performance (e.g., quality of environmental institutions and policies). Nevertheless, environmental concerns are rarely the only reasons for development assistance. The foreign aid literature reveals several donors' underlying motives and priorities, most notably humanitarian, economic, and political $[13,27,28]$; 
it remains to answer the question to what extent these other motives can influence environmental aid itself.

Our paper deals with environmental aid allocations using the example of Czech development aid. There are two main interrelated research questions; firstly, "What is the territorial pattern of Czech environmental aid?" and secondly, "What factors can explain the allocation of Czech environmental aid?" To answer these questions, we have analyzed aid flows from the unique dataset of Czech development projects between 2000 and 2015. To circumvent the problem of a lack of a common definition for the term "environmental assistance" we have classified individual projects using the methodology developed by Hicks and his colleagues [29] which allows for project evaluation according to their likely environmental impact. This step helped us to distinguish environmental aid transfers from other bilateral aid provided by the Czech Republic. Subsequently, we have developed a set of hypothesized relationships based on the environmental priorities and objectives of the Czech development cooperation [23,24]. We employed multivariate regression analyses which enable us to measure the impact of selected factors which could influence the allocation of Czech environmental aid to its recipients. The results show weak or even non-existent influence of environmental factors (when standard factors are controlled for) in the distribution of environmental aid provided by the Czech Republic. While the standard variables explain the Czech environmental aid quite well, environmental variables do not have much impact. The exception is carbon dioxide emissions as a share of gross national income in recipient countries - more environmental aid has been targeted at countries that produce more carbon dioxide to their gross national income.

\section{Materials and Methods}

The factors in aid allocation are usually divided into three basic groups: donors' interests, recipients' needs, and factors of merit. The first group reflects selfish motives in aid allocation and is approximated by variables measuring donors' exports or bilateral trade with recipients or by variables describing different kinds of relationships and closeness between donors and recipients (common colonial links, geographic distance, cultural proximity, etc.). It is predicted that the volume of aid will be positively influenced by the intensity of donors' interests and by the proximity of mutual relationships [30-35].

The recipients' needs for aid reflect the altruistic motives of aid allocation and can be divided into two basic subcategories. Economic needs are usually measured by the level of economic development (gross domestic product-GDP per capita, for example), while social needs may be approximated by many diverse indicators of social development such as literacy rate, life expectancy, infant mortality rate, or caloric intake $[25,26,36]$. The theory of altruism suggests that greater needs should be associated with greater volumes of aid. Most of environmental aid fits into this category of recipients' environmental needs which can be approximated in accordance to the donors' objectives for environmental aid. For instance, when drinking water supply is of high relevance for a donor's interventions, then renewable internal freshwater resources per capita would be a relevant indicator. Similarly, biodiversity needs may be measured by the International Union for Conservation of Nature (IUCN) Red List Index and promotion of sustainable use of natural resources in developing countries by an ecological footprint indicator.

The third group of factors reflects the merit in aid allocation. In this context, indicators of institutional quality and political development are used, such as the different sub-indices (or the average) of the Worldwide Governance Indicators, the level of civil liberties and political rights, and the type of political regime. According to this merit hypothesis, it is assumed that donors reward better institutional performance of recipients by giving them more aid (and this reward logic is also applied to the desired type of political regime, i.e., the preference of democracy over autocracy, or to a greater extent of freedoms). This is also supported by Collier's and Dollar's influential study [37], according to which the quality of recipient countries' institutions has a positive influence on aid effectiveness. Although the findings of this study have been criticized [38], it provided the basis for 
political conditionality of foreign aid. The merit argument may be relevant also for environmental aid: donors may decide to reward developing countries with better environmental performance of a government's policies with more generous aid flows.

In line with the above-mentioned review of standard factors of aid allocation [25,30-32,34-39] and taking into consideration previous research on aid allocations of post-communist Central European countries $[33,40]$, we adopt the following default model in our research of determinants of Czech environmental aid over the period 2000-2015:

$$
\begin{aligned}
\ln _{\text {enviaid }_{\text {cp } 1(\mathrm{i}, \mathrm{t})}=} & \alpha+\beta 1 \ln \_g d p \_p c(i, \mathrm{t})+\beta 2 \mathrm{u} 5 \operatorname{mort}(\mathrm{i}, \mathrm{t})+\beta 3 \ln \_ \text {population }(\mathrm{i}, \mathrm{t}) \\
& +\beta 4 \operatorname{comecon}(\mathrm{i})+\beta 5 \operatorname{embassy}(\mathrm{i}, \mathrm{t})+\beta 6 \ln \_\operatorname{trade} \_\mathrm{cp}(\mathrm{i}, \mathrm{t}) \\
& +\beta 7 \operatorname{dist}(\mathrm{i})+\beta 8 \text { freedom }(\mathrm{i}, \mathrm{t})+\beta 9 \ln \_ \text {czaid } 1 \\
& +\beta 10 \text { environmental_factor }+\varepsilon(\mathrm{i}, \mathrm{t})
\end{aligned}
$$

In the Equation (1), $t$ stands for time, i stands for a particular recipient, $\varepsilon$ is the error term and $\alpha$ and $\beta$ s are the regression coefficients to be estimated. Understandably, the coefficient of our utmost interest is the coefficient for the different environmental variables ( $\beta 10)$. We add the environmental factors one-after-one alongside the standard allocation specification ( $\beta 1-\beta 9)$ and examine their direction (sign)

\begin{tabular}{|c|c|c|c|}
\hline $\begin{array}{l}\text { Name Used in } \\
\text { Regressions }\end{array}$ & Description & Unit & Data Source \\
\hline ln_gdp_pc & $\begin{array}{l}\text { GDP per capita of recipient } \\
\text { countries } \\
\text { (recipients' economic needs) }\end{array}$ & $\begin{array}{l}\text { international dollars in purchasing } \\
\text { power parity, constant prices of } 2011 \\
\text { (in ln-transformation) }\end{array}$ & World Bank [41] \\
\hline u5mort & $\begin{array}{l}\text { under-5 (years) mortality rate of } \\
\text { recipient countries } \\
\text { (recipients' social needs) }\end{array}$ & $\begin{array}{c}\text { number of deaths (of children } \\
\text { younger than } 5 \text { years of age) per } 1000 \\
\text { live births }\end{array}$ & World Bank [42] \\
\hline comecon & $\begin{array}{l}\text { historical relations of a recipient to } \\
\text { the Council for Mutual Economic } \\
\text { Assistance (COMECON); the } \\
\text { Czech Rep. was a member state } \\
\text { (special historical proximity) }\end{array}$ & $\begin{array}{l}\text { dummy variable (equals } 1 \text { if a } \\
\text { recipient was a member, associate } \\
\text { member, observer or cooperated with } \\
\text { COMECON) }\end{array}$ & Zwass [44] \\
\hline ln_trade_cp & $\begin{array}{l}\text { Czech bilateral trade with a given } \\
\text { recipient country } \\
\text { (donor's economic interests) }\end{array}$ & $\begin{array}{c}\text { Czech currency (CZK), constant prices } \\
\text { of } 2010 \\
(\text { in ln-transformation })\end{array}$ & Czech Statistical Office [46] \\
\hline dist & $\begin{array}{l}\text { distance between Prague and the } \\
\text { capital of a given recipient country } \\
\text { (donor's regional interests) }\end{array}$ & kilometers & CEPII [47] \\
\hline freedom & $\begin{array}{c}\text { Index of Freedom of a recipient } \\
\text { country } \\
\text { (factor of merit) }\end{array}$ & $\begin{array}{c}\text { index; average of two sub-indices } \\
\text { (civil liberties and political rights); } \\
\text { takes values from } 1 \text { (most free) to } 7 \\
\text { (least free) }\end{array}$ & Freedom House [48] \\
\hline
\end{tabular}
and statistical significance. The standard determinants of aid allocation in Equation (1) are summarized in Table 1.

Table 1. Description of the standard allocation factors.

The dependent variable in the standard allocation research is most frequently the volume of total aid disbursed by a donor to its recipient countries. However, most donors provide aid only to a certain portion of all eligible recipients which creates the issue of zero aid allocations, i.e., situations when a donor does not provide any aid to eligible recipients. This is crucial because it basically determines the appropriate method of regression analyses. If the issue of zero allocations is completely 
ignored, then the ordinary least squares (OLS) or the traditional panel data techniques such as pooled OLS, random effects, or fixed effects estimations may be used. However, if the zero observations are taken into account as (zero) allocations, methods that can deal with the truncated nature of the dependent variable must be employed. In the allocation literature, three types of regression methods have been used: (i) the independent two-step procedures, i.e., the probit or logit method in the first stage combined with OLS or panel data methods in the second stage [31,34]; (ii) the two-step Heckman model [31,50]; (iii) one step tobit model $[22,25,26,30,51]$. We opt for the tobit model not only because we must account for the zero allocations (since there are simply too many of them), but also because it can be readily used with panel data (although only with random effects). Moreover, the random-effect tobit model has already been employed to deal with the factors of Czech development assistance allocation $[22,40]$, therefore we prefer to apply it once again so that the results on environmental aid are directly comparable to the ones on total aid.

In our analysis, however, we are most interested in the influence of environmental explanatory variables on the amount of Czech environmental aid, which is our dependent variable. For its definition, we use the methodology developed by Robert L. Hicks and his colleagues [29]. This methodology is, to our best knowledge, the only one that allows us to assess the likely environmental impacts of individual aid projects. Original methodology distinguishes three main environmental categories of aid projects- "green" projects that are likely to be positive in their environmental impact, "dirty" projects that are likely to have negative environmental impacts, and "neutral" projects which are considered neither harmful nor beneficial to the environment [29]. Our paper works with the first category of green aid transfers. The transfers were determined from a database of more than 800 aid projects funded by the Czech Republic during the period 2000-2015. The only minor modification (or specification) of the original methodology was the inclusion of organic farming projects into the clean aid category due to the generally recognized environmental benefits of organic farming [52-54]. The variable is used in the regression analysis in thousands of the Czech currency (CZK, in constant prices of 2010).

The environmental objectives of Czech environmental aid and environmental variables factors approximating the objectives are summarized in Table 2. The selection of indicators was based on two key conditions. Firstly, they should be meaningful in approximating the objectives stated in the two development cooperation strategies of the Czech Republic. Secondly, they should contain as many observations as possible for each recipient country for the purpose of the regression analyses. The second prerequisite proved to be very restrictive in the process of variable selection. Several environmental indicators are available only to a limited number of countries (this is true for the more developed countries in particular). In some cases, records were missing especially for less recent periods. The final list includes seven variables; the first six are related to the environmental needs of recipients, the seventh represents environmental performance of recipient countries. The hypothesized relationship describes the logic behind the selection of each variable.

Table 2. Description of the environmental allocation factors.

\begin{tabular}{|c|c|c|c|c|}
\hline Objective & Indicator/Factor & $\begin{array}{l}\text { Name Used in } \\
\text { Regressions }\end{array}$ & Hypothesized Relationship & Data Source \\
\hline $\begin{array}{l}\text { Water supply and water } \\
\text { resource protection }\end{array}$ & $\begin{array}{l}\text { Renewable internal } \\
\text { freshwater resources per } \\
\text { capita (in cubic meters) }\end{array}$ & freshwater & $\begin{array}{l}\text { Higher water scarcity thread } \\
\text { >> more environmental aid }\end{array}$ & $\begin{array}{c}\text { Food and } \\
\text { Agriculture } \\
\text { Organization [55] }\end{array}$ \\
\hline $\begin{array}{l}\text { Protection against natural } \\
\text { hazards and disasters }\end{array}$ & $\begin{array}{c}\text { Droughts, floods, extreme } \\
\text { temperatures (\% of } \\
\text { population, average } \\
1990-2009)\end{array}$ & $D f t$ & $\begin{array}{l}\text { Higher risk of natural } \\
\text { hazards and disasters >> } \\
\text { more environmental aid }\end{array}$ & World Bank [56] \\
\hline $\begin{array}{l}\text { Transfer of advanced } \\
\text { environmental } \\
\text { technologies and } \\
\text { reductions in energy } \\
\text { consumption }\end{array}$ & $\begin{array}{c}\mathrm{CO}_{2} \text { emissions } \\
(\mathrm{kg} \text { per PPP } \$ \text { of GDP) }\end{array}$ & $c o 2 g d p$ & $\begin{array}{l}\text { Higher carbon intensity of } \\
\text { industry }>>\text { more } \\
\text { environmental aid }\end{array}$ & World Bank [57] \\
\hline
\end{tabular}


Table 2. Cont.

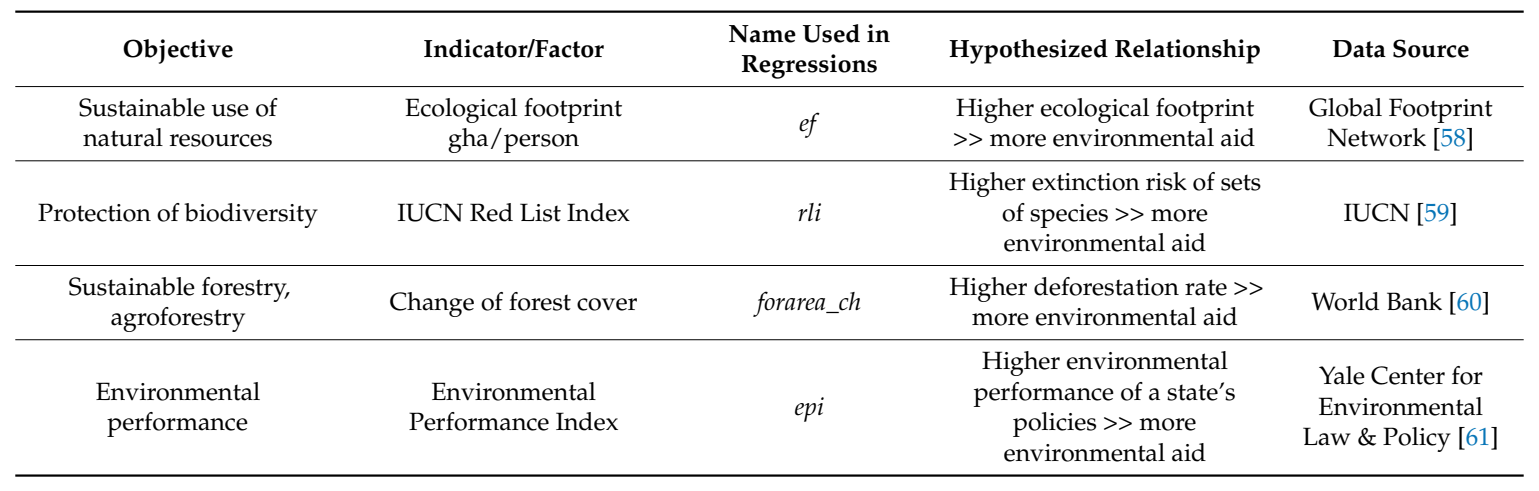

Water scarcity is a rapidly growing concern around the globe, the population under water scarcity increased from $14 \%$ of global population in the 1900 s to $58 \%$ in the 2000s [62], and moreover, undergoing climate change is likely to exacerbate regional and global water scarcity considerably [63]. Delivering clean water is crucial for public health and human development $[64,65]$. To address water scarcity challenge in developing countries, the Czech Republic has been engaged in water supply and water resource protection in partner countries $[23,24]$. In this regard we employ the variable "renewable internal freshwater resources per capita" (in cubic meters), which refer to internal renewable resources (internal river flows and groundwater from rainfall) in the country. This variable is available for all countries in our dataset [55]. The indicator correlates with other water stress related indicators, such as Falkenmark indicator [66] or Basic Human Water Requirements [67]. We hypothesize that the higher water scarcity threat is (as measured by renewable freshwater resources per capita), the higher the magnitudes of aid should be.

Natural disasters have negative impacts on households' wellbeing [68,69]. Although a natural disaster can cause a short term spur of GDP growth as a result of a post-disaster reconstruction, it undermines sustained long-term economic growth of developing countries [70,71]. Official development strategies repeatedly mention protection against natural hazards and disasters as an important objective of Czech development cooperation [23,24]. Accordingly, higher risk of natural hazards and disasters in a given country (approximated by percentage of population affected by droughts, floods, and extreme temperatures over the period 1990-2009 [56]) should have impact on an increased aid flows.

The leitmotiv of Czech development cooperation is the transfer of Czech "transition experience" to less developed countries [72,73]. This also applies to transfer of environmental know-how, reduction in energy consumption and support of renewable sources of energy [23,24]. The Czech economy has indeed experienced the decrease in energy intensity $[5,74,75]$, and part of the decrease is attributable to improvements in energy efficiency [76]. Moreover, it belongs among those EU countries which were able to decrease their $\mathrm{CO}_{2}$ emissions significantly $[6,76]$. We hypothesize that a higher carbon intensity of a nation's economy should attract more environmental funds to increase the energy efficiency and decrease carbon intensity of aid recipients. The carbon intensity is approximated by the carbon dioxide emissions (in kilograms per PPP \$ of GDP) [57].

Sustainable management of natural resources is another overreaching objective which reflects current development paradigm [77-79] and which is mirrored within objectives of the Czech development cooperation $[23,24]$. Sustainable use of natural resources is approximated in our paper by ecological footprint, an indicator which attempts to determine the biologically productive area needed to support the consumption of a given population indefinitely [80]. Despite its methodological weakness [81], the index is widely used as a measure of sustainability on various geographical levels [82]. We hypothesize that the volume of Czech environmental aid allocation should increase with a higher ecological footprint (which indicates less sustainable use of natural resources). 
Biodiversity is one of important public goods and biodiversity protection includes activities whose main scope is the global environment [12]. Biodiversity loss is recognized by the international community as one of the most serious global environmental threats $[83,84]$. Despite the fact that socio-economic benefits of biodiversity conservation remain controversial and under debate $[85,86]$, both international and bilateral donors are involved in efforts towards protection of biodiversity. If Czech development cooperation objective is to protect biodiversity in developing countries [23,24], it is reasonable to expect that more aid will be allocated to countries with higher threat to biodiversity. To approximate the biodiversity decline, internationally recognized IUCN Red List Index [87] has been employed. The index shows trends in the projected overall extinction risk of sets of species $[84,88]$ while taking into the consideration uneven distribution of biodiversity.

Change of the forest cover of individual countries is sometimes regarded as a biodiversity indicator, because forests (and notably tropical rain forests) harbor considerable part of world's biodiversity and endangered species [89]. Apart from biodiversity loss, deforestation is a significant cause of global carbon emissions [90]. Last but not least, forests are important for the wellbeing of the poor because they provide a source of regular subsistence for people who live in and near forests [91]. Tropical and subtropical agriculture and forestry were among priority areas of foreign aid provided by former communist Czechoslovakia [92], the expertise has been preserved by Czech universities and is reflected in current projects of Czech foreign aid. Change of the forest cover is a suitable indicator of forests loss [93] and data are available for all countries [60]. We hypothesize that the higher is deforestation rate, the greater should be the need for Czech environmental aid.

The final indicator is dedicated to environmental performance of environmental aid recipients. In theory, donors should reward better environmental performances of recipients with higher volumes of aid. The development performance is linked by many authors to institutional quality [32,94,95], and the significance of institutional quality as a determinant of aid allocation depends on the variables used to measure it [96]. The obstacle here is the lack of suitable environmental performance indicators for developing countries due to data unavailability. The only indicator which provides comprehensive records is Environmental Performance Index (EPI) which was developed by Yale Center for Environmental Law \& Policy [61,97]. EPI is a composite indicator which ranks 180 countries in ten priority environmental issues covering two dimensions - environmental health and ecosystem vitality [97]. Another promising indicator is also the Environmental Democracy Index which attempts to evaluate the state of national laws protecting transparency, participation, and justice in environmental decision-making [98]. Therefore, it appears to be an ideal measure for approximating the environmental performance of recipient countries. Yet it provides records for only 70 countries, which is an insufficient amount given our broader dataset.

To summarize this section, in our study we examine the factors of Czech environmental aid allocation to recipient countries over the period 2000-2015 and we particularly focus on the environmental explanatory variables. These are alternated one-after-one in the default model (1) alongside the set of standard allocation factors. The recipients are defined in accordance with the OECD Development Assistance Committee (DAC) as countries eligible to receive development assistance at any time over the defined period. Thus, we can make use of panel data that have the cross-section element of 156 recipients and time element of 16 years. Because we want to analyze the allocation processes including the many zero observations on the dependent variable (almost $90 \%$ of the zero allocations in some specifications) using our panel data, we apply the random-effects tobit model. Since this technique rests on the assumption of homoscedasticity, we transform the dependent variable using the natural logarithm.

\section{Results}

The first objective of our paper is to evaluate the territorial pattern of Czech environmental aid. Top receivers of Czech environmental aid are shown in Table 3. The figure indicates a high correlation between the top recipients of Czech environmental aid and so called "priority countries" of Czech 
development cooperation. Seven out of ten beneficiaries of environmental aid were priority countries for Czech development assistance. The first four countries (Serbia, Moldova, Bosna and Herzegovina, and Mongolia) were listed by both strategic documents of the Czech development cooperation. The other three (Vietnam, Ethiopia, and Yemen) were included in one of the two strategies. Only the last three countries (Ukraine, Kyrgyzstan, and Peru) were not among the priority countries of Czech development cooperation. The list of countries indicates that a considerable amount of environmental aid has been allocated to former communist countries or to countries with leftist regimes during the Cold War period.

Table 3. Top ten recipients of Czech environmental aid.

\begin{tabular}{cccc}
\hline Recipient Country & $\begin{array}{c}\text { Priority Country } \\
\mathbf{2 0 0 2 - 2 0 0 7}\end{array}$ & $\begin{array}{c}\text { Priority Country } \\
\mathbf{2 0 1 0 - 2 0 1 7}\end{array}$ & $\begin{array}{c}\text { Total Environmental Aid } \\
\mathbf{2 0 0 0 - 2 0 1 5} \text { (Million Euros) }\end{array}$ \\
\hline Serbia & yes & yes & 9.31 \\
\hline Moldova & yes & yes & 8.47 \\
\hline Bosnia and Herzegovina & yes & yes & 7.30 \\
\hline Mongolia & yes & yes & 6.23 \\
\hline Viet Nam & yes & no & 3.13 \\
\hline Ethiopia & no & yes & 2.45 \\
\hline Yemen & yes & no & 2.31 \\
\hline Ukraine & no & no & 1.99 \\
\hline Kyrgyzstan & no & no & 1.48 \\
\hline Peru & no & no & 1.25 \\
\hline
\end{tabular}

Source: Development Cooperation Strategy for 2002-2007 [23]; Development Cooperation Strategy of the Czech Republic 2010-2017 [24]; authors' own calculations.

The list of environmental aid recipients indicates certain biases of Czech environmental aid. This may raise the question of what factors affect territorial allocation of Czech environmental aid. Has the Czech environmental aid responded to the environmental needs of developing countries? Or did the Czech government reward environmental performance of partner countries? And what if the Czech environmental aid may not be directly linked to the recipient countries' environmental needs or performance? To tackle these questions while accounting for the zero allocations and using our panel data, we have employed the random-effects tobit regression model whose results are presented in Table 4.

From the results it is apparent that the standard allocation variables (column 1) explain the Czech environmental aid quite well. The Czech Republic gives more environmental aid to countries with lower levels of GDP, lower children's mortality rates, higher populations, to countries that share similar historical experience (that were closely related to COMECON), where a Czech embassy is present, and countries that enjoy higher levels of freedom. Also, the Czech Republic provides more environmental aid to countries to which it allocates more aid in general. In contrast, it seems that trade links and geographical distance do not play a role in the allocations of Czech environmental aid. These results hold in the majority of the eight models presented in Table 4, with minor modifications in statistical significance for some of the variables: the population variable is insignificant in models (2), (3) and (8), the embassy variable is not significant in models (2) and (8) and the freedom variable is insignificant in model (2). However, this variation in significance levels can be also caused by different numbers of observations in the individual models. The findings from model (1) are in fact very similar to those of the total Czech aid [22,40], there are only minor differences (e.g., the trade links were a significant factor of the total Czech aid, as well as the geographical distance). 
Table 4. Results of the regression analysis.

\begin{tabular}{|c|c|c|c|c|c|c|c|c|}
\hline \multirow{3}{*}{ Models // Variables } & \multicolumn{8}{|c|}{ Dependent Variable: ln_Enviaid_cp1. Estimation Method: Random-Effects Tobit Model } \\
\hline & (1) & (2) & (3) & (4) & (5) & (6) & (7) & (8) \\
\hline & none & freshwater & dft & co2gdp & ef & rli & forarea_ch & epi \\
\hline \multirow{2}{*}{$\ln$-gdp-pc } & $-3.750^{* *}$ & $-5.434^{* *}$ & $-3.721^{* *}$ & $-3.298^{*}$ & $-4.556^{* *}$ & $-3.624^{* *}$ & $-3.725^{* *}$ & $-4.387^{* *}$ \\
\hline & $(1.732)$ & $(2.295)$ & $(1.818)$ & $(1.801)$ & $(2.011)$ & $(1.705)$ & $(1.728)$ & $(2.178)$ \\
\hline \multirow{2}{*}{ u5mort } & $-0.119^{* * *}$ & $-0.164^{* *}$ & $-0.119^{* * *}$ & $-0.122^{* * *}$ & $-0.132^{* * *}$ & $-0.129^{* * *}$ & $-0.121^{* * *}$ & $-0.141^{* * *}$ \\
\hline & $(0.036)$ & $(0.066)$ & $(0.036)$ & $(0.037)$ & $(0.038)$ & $(0.036)$ & $(0.036)$ & $(0.054)$ \\
\hline \multirow{2}{*}{ ln-population } & $2.077^{* *}$ & 0.667 & 1.480 & $2.039 * *$ & $1.926^{*}$ & $2.387^{* *}$ & $2.053^{* *}$ & 1.872 \\
\hline & $(0.991)$ & (1.296) & $(1.019)$ & $(0.991)$ & (1.035) & $(1.008)$ & $(0.989)$ & (1.188) \\
\hline \multirow{2}{*}{ comecon } & $9.849^{* * *}$ & $10.376^{* * *}$ & $8.767^{* * *}$ & $7.755^{* * *}$ & $9.213^{* * *}$ & $9.605^{* * *}$ & $9.855^{* * *}$ & $7.743^{* *}$ \\
\hline & $(2.794)$ & $(2.893)$ & $(2.834)$ & $(2.917)$ & $(2.814)$ & $(2.734)$ & $(2.790)$ & $(3.022)$ \\
\hline \multirow{2}{*}{ embassy } & $4.286^{* *}$ & 3.864 & $4.916^{* * *}$ & $4.209^{* *}$ & $4.372^{* *}$ & $4.119 * *$ & $4.375^{* * *}$ & 2.014 \\
\hline & $(1.670)$ & $(2.978)$ & (1.788) & $(1.734)$ & (1.753) & $(1.664)$ & $(1.670)$ & $(1.770)$ \\
\hline \multirow{2}{*}{ ln-trade-cp } & -0.764 & 0.118 & -0.641 & -0.821 & -0.744 & -0.763 & -0.767 & -1.020 \\
\hline & $(0.605)$ & $(0.921)$ & $(0.620)$ & $(0.609)$ & $(0.633)$ & $(0.596)$ & $(0.605)$ & $(0.774)$ \\
\hline \multirow{2}{*}{ dist } & 0.085 & 0.639 & 0.178 & 0.190 & 0.101 & 0.390 & 0.073 & 0.570 \\
\hline & $(0.377)$ & $(0.451)$ & $(0.390)$ & $(0.387)$ & $(0.381)$ & $(0.411)$ & $(0.377)$ & $(0.411)$ \\
\hline \multirow{2}{*}{ freedom } & $-1.781^{* * *}$ & -1.184 & $-1.508^{* *}$ & $-1.651^{* *}$ & $-1.751^{* * *}$ & $-1.804^{* * *}$ & $-1.730^{* * *}$ & $-2.267^{* * *}$ \\
\hline & $(0.656)$ & $(0.743)$ & $(0.667)$ & $(0.675)$ & $(0.664)$ & $(0.646)$ & $(0.655)$ & $(0.743)$ \\
\hline \multirow{2}{*}{ ln-czaid1 } & $2.099^{* * *}$ & $2.844^{* * *}$ & $2.074^{* * *}$ & $2.263^{* * *}$ & $2.029^{* * *}$ & $2.082^{* * *}$ & $2.097^{* * *}$ & $4.149^{* * *}$ \\
\hline & $(0.285)$ & $(0.637)$ & $(0.286)$ & $(0.303)$ & $(0.288)$ & $(0.285)$ & $(0.285)$ & $(0.571)$ \\
\hline \multirow{2}{*}{-cons } & -9.682 & 8.769 & -3.517 & -15.688 & 0.012 & -36.971 & 35.117 & -4.873 \\
\hline & (20.398) & (25.166) & (21.123) & (21.576) & (21.514) & $(26.942)$ & (42.068) & (23.088) \\
\hline \multirow{3}{*}{$\begin{array}{l}\text { environmental } \\
\text { variables }\end{array}$} & \multirow{3}{*}{ none } & freshwater & $\mathrm{dft}$ & co2gdp & ef & rli & forarea_ch & epi \\
\hline & & 0.000 & 0.343 & $9.353^{* * *}$ & 0.398 & 23.592 & -44.685 & 0.009 \\
\hline & & $(0.000)$ & $(0.569)$ & $(2.521)$ & $(0.842)$ & (14.743) & $(36.782)$ & $(0.141)$ \\
\hline \multirow{2}{*}{ sigma-u } & $7.797^{* * *}$ & 1.757 & $7.795^{* * *}$ & $7.842^{* * *}$ & $7.700^{* * *}$ & $7.569^{* * *}$ & $7.775^{* * *}$ & $6.319^{* * *}$ \\
\hline & (1.256) & (3.407) & $(1.265)$ & $(1.294)$ & $(1.250)$ & $(1.226)$ & (1.253) & (1.198) \\
\hline \multirow{2}{*}{ sigma-e } & $7.488^{* * *}$ & $8.714^{* * *}$ & $7.462^{* * *}$ & $7.244^{* * *}$ & $7.425^{* * *}$ & $7.484^{* * *}$ & $7.476^{* * *}$ & $5.339^{* * *}$ \\
\hline & $(0.452)$ & $(1.368)$ & $(0.457)$ & $(0.449)$ & $(0.458)$ & $(0.452)$ & $(0.452)$ & $(0.435)$ \\
\hline \multirow{2}{*}{ rho } & 0.520 & 0.039 & 0.522 & 0.540 & 0.518 & 0.506 & 0.520 & 0.583 \\
\hline & $(0.080)$ & $(0.151)$ & $(0.081)$ & $(0.082)$ & $(0.081)$ & $(0.081)$ & $(0.080)$ & $(0.096)$ \\
\hline LR test $($ sig- $\mathrm{u}=0$ ) & $112.22^{* * *}$ & 0.07 & $111.86^{* * *}$ & $107.34^{* * *}$ & $106.21^{* * *}$ & $103.77^{* * *}$ & $111.93^{* * *}$ & $60.11^{* * *}$ \\
\hline Wald $\mathrm{Chi}^{2}$ & $106.82^{* * *}$ & $44.13^{* * *}$ & $100.45^{* * *}$ & $104.48^{* * *}$ & $100.31^{* * *}$ & $108.94^{* * *}$ & $107.56^{* * *}$ & $77.95^{* * *}$ \\
\hline Observations & 2256 & 534 & 1870 & 2100 & 1975 & 2256 & 2253 & 1211 \\
\hline Censored obs. & 2057 & 496 & 1677 & 1911 & 1784 & 2057 & 2054 & 1101 \\
\hline No. of recipients & 148 & 138 & 121 & 146 & 139 & 148 & 147 & 138 \\
\hline
\end{tabular}

Notes: Standard errors of the estimates are in parentheses. The level of significance: ${ }^{* * *} 1 \%$; ${ }^{* *} 5 \%$; $10 \%$. The term "In_" means that the variable entered regressions in logarithmic form; sigma_e is the overall variance component and sigma_u the panel-level variance component; $r$ ro is the percent contribution of sigma_u to the total variance. To test whether rho is zero (or that sigma_u is unimportant), a likelihood ratio (LR) test is presented. The insignificance of the test (model 2) indicates that the panel estimator is the same as the pooled estimator. The Wald Chi-square test examines whether at least one of the predictors' regression coefficient is different from zero and it is significant for all models.

In the rest of the models (2) to (8), the environmental variables have been added one-after-one alongside the set of the standard allocation variables: in the model (2), the freshwater variable has been added next to the set of standard variables, in the model (3), the freshwater variable has been removed and replaced by the $\mathrm{dft}$ variable, in the model (4), we have replaced the $\mathrm{dft}$ variable by 
the co2gdp variable, etc. The results show that once the standard allocation variables are controlled for, almost none of the environmental variables are significant. There are only two exceptions. First, the proportion of $\mathrm{CO}_{2}$ on the GDP of recipients is a positive and significant determinant of Czech environmental aid (model 4). This means that countries that produce higher levels of $\mathrm{CO}_{2}$ (relative to the size of their economy) receive more Czech environmental aid. The second exception is the red list index variable which is positive and only narrowly insignificant (it would be significant at the $11 \%$ level; model 6). It suggests that the recipients with higher extinction risk of some sets of species receive more environmental aid from the Czech Republic. The rest of the environmental explanatory variables, however, are clearly insignificant, which indicates that none of them correlate with the amounts of the Czech environmental aid once the standard independent allocation variables are controlled for. Therefore, we have also checked whether there are (at least) bivariate correlations between the flows of the Czech environmental aid on one side, and the individual environmental factors on the other side. The correlation coefficients and their significances are presented in Table 5.

Table 5. Correlation coefficients between Czech environmental aid and environmental factors.

\begin{tabular}{cccccccc}
\hline Variable & freshwater & dft & co2gdp & ef & rli & forarea_ch & epi \\
\hline Expected sign & - & + & + & + & + & - & + \\
\hline Correlation coeff. & -0.0435 & $-0.0369^{*}$ & $0.1564^{* * *}$ & $0.0451^{* *}$ & $0.1111^{* * *}$ & $0.0632^{* * *}$ & $0.0496^{*}$ \\
\hline Notes: Standard errors of the estimates are in parentheses. The level of significance: & ${ }^{* * *} 1 \%{ }^{* *} 5 \%{ }^{*} 10 \%$.
\end{tabular}

While the bivariate relationships display more statistical significance, the values of the correlation coefficients are low (perhaps with the exceptions of the co2gdp and rli variables), indicating a low strength of the bivariate associations between the volumes of Czech environmental aid and the individual environmental variables. It is also shown that for two variables, namely $\mathrm{dft}$ and forarea_ch, the signs of the correlation coefficients do not correspond with the theoretical expectations. This result is surprising and most likely it is the consequence of the imperfect data we work with. Another possibility would be that both variables reflect rather some merit in the Czech environmental aid than environmental needs of the recipients, which is not likely in our opinion. However, statistical significance of all results is weakened substantially when the correlations are performed separately for each year: only the co2gdp and rli variables remain significant (in most cases), which is consistent with the results of the regression analysis.

\section{Discussion}

The study yielded some interesting results regarding the pattern of Czech environmental flows. It can be stated that only a few objectives of the Czech environmental aid are being translated into real aid flows. The first objective is "Transfer of advanced environmental technologies and reductions in energy consumption." The reason for the prioritization of green technologies may be related to the Czech expertise acquired in the process of reducing environmental burdens inherited from the communist era prior to 1989. The Czech Republic was able to reduce its energy intensity and decrease $\mathrm{CO}_{2}$ emissions significantly [6,74], partly due to improvements in energy efficiency and environmental engineering $[6,99]$. The prioritization of environmental knowledge transfers can be also seen as an attempt to clear the way for export of Czech technological companies to emerging markets. In other words, donors may support these activities in expectation of future economic benefits and business opportunities in the form of an export for their technologies or expert services. The main aim of such a policy is economic development with environmental sustainability as a secondary or side effect [12]. This is not a problem if the projects are aligned to the real needs identified by partners in developing countries. If not, such an approach is merely export promotion policy where business interests prevail over the needs of developing countries - this kind of donor behavior could undermine the sustainability of development efforts. 
The second and last objective which is mirrored in the real aid allocations is the "Protection of biodiversity." Unlike the first objective, the benefits from biodiversity protection (where the main scope is the global environment) cannot be easily captured by individual donors [12]. Although biodiversity conservation is among the Sustainable Development Goals [14], it should be acknowledged by policymakers that relationship between conservation needs and the demands of poverty reduction is complex and sometimes conflicting $[15,16,18,100]$. The evidence shows that the establishment of strict protected areas can have substantial negative impacts on local people's wellbeing $[69,70,101]$, while other authors indicate that nature conservation may actually provide income-generating opportunities for poor people [102-104]. Last but not least, poverty can be seen as a critical obstacle of conservation, if, for instance, poor people are engaged in the overharvesting of wild species or colonizing biodiverse land [85]. Given the complex nature of the poverty-environment nexus, administrators of development assistance programs must ensure that biodiversity-related projects do not compromise poverty alleviation efforts.

Several statistically significant variables which explain the allocations of Czech environmental aid are not related to the environmental needs or performance of recipient countries. This means that variables other than environmental objectives are influencing environmental aid transfers. Among the non-environmental factors are historical relations with developing countries, development needs as well as organizational factors (presence of a Czech embassy). Perhaps the most important observation is the fact that more environmental aid is allocated to the countries which received more Czech aid in general. Some of these findings can be compared with Hicks's study [29], although differences in the variables used do not allow a full comparison. For instance, the physical proximity of recipient countries is not a predictor of environmental aid provided by the Czech Republic; the same is true for donors included in the Hicks's study. Similarity, it can also be found in the statistical significance of historical ties, although in the Hicks study these are colonial ties, while in our study, these ties are from the period of communist regimes. There are differences in the case of trade relations; bilateral trading partners are favored by donors according to Hicks's study, while in our case, trade relations were not a significant predictor of environmental aid allocations.

The main policy implication of this study is related to the fact that the Czech Republic is insufficiently responsive not only to developing countries' environmental needs and performance, but also to its own environmental objectives. Moreover, statistical analysis revealed only minor differences in the allocation of environmental aid vis-á-vis overall Czech aid. Setting clear criteria for allocating environmental aid would increase its transparency and facilitate the assessments of governmental development aid strategies. However, the effort to measure and quantify environmental needs or performance of developing countries can be hindered by methodological limits. Developing countries suffer from weak data-collection capabilities, therefore finding usable variables especially for the poorest countries can be difficult. Equally challenging is the question of representativeness of indicators, which are meant to approximate environmental need and performance of developing countries. The use of national annual averages tends to obscure important information at smaller scales. Finally, the categorization and coding scheme by Hicks and his colleagues [29] refers to likely environmental effects of development aid projects not to actual environmental impacts. These limits should be taken into account when interpreting the results and using them for policy purposes.

\section{Conclusions}

The paper examines factors affecting allocations of environmental aid to developing countries using the Czech Republic as a case study. Environmental goals stated in strategic documents approved by the Czech government are compared with the actual pattern of environmental aid transfers. The results point to a relatively weak responsiveness of Czech environmental aid to the environmental needs or performance of developing countries. Only two out of the seven factors which approximated official environmental objectives had been reflected in environmental aid transfers. Specifically, more environmental aid had been provided to countries with higher $\mathrm{CO}_{2}$ emissions 
per capita and to countries with a higher risk of biodiversity decline. The prioritization of green technologies and knowledge transfers corresponds with the expertise in qualitative improvements of the environment acquired by the Czech Republic after the fall of communist regime. Finally, the fact that other variables such as historical ties or significantly influence environmental aid indicates, that non-environmental objectives affect Czech environmental aid to a considerable degree. The study points to the methodological challenges and recommends setting clear measurable indicators which will improve the transparency of donors' environmental aid.

Author Contributions: Z.O. instigated and conceptualized the research project, contributed to the literature review, and drafted the manuscript. J.H. contributed to the literature review, data analysis and provided feedback on the manuscript drafts.

Funding: This research received no external funding.

Conflicts of Interest: The authors declare no conflict of interest.

\section{References}

1. Moldan, B.; Schnoor, J. Czechoslovakia: Examining a critically ill environment. Environ. Sci. Technol. 1992, 26, 14-21. [CrossRef]

2. Nováček, P.; Mederly, P. Czech and Slovak Studies of Sustainable Development. Ekológia 1995, 14, 79-85.

3. Fagin, A.; Jehlička, P. Sustainable development in the Czech Republic: A doomed process? Environ. Polit. 1998, 7, 113-128. [CrossRef]

4. Fagin, A. Environment and transition in the Czech republic. Environ. Polit. 1994, 3, 479-494. [CrossRef]

5. Moldan, B.; Hak, T. Central European Environmental History and the EU Accession. Environ. Sci. Technol. 2011, 45, 3823-3828. [CrossRef] [PubMed]

6. Moldan, B.; Hak, T. Environment in the Czech Republic: A positive and rapid change. Environ. Sci. Technol. 2007, 358-362. [CrossRef]

7. Fagin, A. Environmental Capacity Building in the Czech Republic. Environ. Plan. A 2001, 33, 589-606. [CrossRef]

8. Bitta, J.; Jančík, P.; Ponocná, T.; Prášek, J.; Vočařová, K. Visegrad Group Countries' Environmental Performance: History and Current State. In Visegrad Countries: Environmental Problems and Policies; Šauer, P., Švihlová, D., Dvořák, A., Lisa, A., Eds.; CENIA, Czech Environmental Information Agency: Prague, Czech Republic, 2013; pp. 46-64. ISBN 978-80-85087-16-1.

9. OECD. Environmental Performance Reviews: Czech Republic (2005); OECD Publications: Paris, France, 2005; ISBN 92-64-01178-1.

10. Bízková, R. The Environment in the Czech Republic 1989-2004; CENIA, Czech Environmental Information Agency: Prague, Czech Republic, 2005; ISBN 80-85087-56-1.

11. Du Pisani, J.A. Sustainable development-historical roots of the concept. Environ. Sci. 2006, 3, 83-96. [CrossRef]

12. Heltberg, R.; Nielsen, U. Foreign aid, development and environment. In Foreign Aid and Development: Lessons Learnt and Directions for the Future; Tarp, F., Ed.; Routledge: London, UK; New York, NY, USA, 2000; pp. 271-289. ISBN 0-415-23363-1.

13. Degnbol-Martinussen, J.; Engberg-Pedersen, P. Aid: Understanding International Development Cooperation; Zed Books: London, UK; New York, NY, USA, 2003; ISBN 1-84277-038-1.

14. Hák, T.; Janoušková, S.; Moldan, B. Sustainable Development Goals: A need for relevant indicators. Ecol. Indic. 2016, 60, 565-573. [CrossRef]

15. Duraiappah, A.K. Poverty and Environmental Degradation: A Review and Analysis of the Nexus. World Dev. 1998, 26, 2169-2179. [CrossRef]

16. Dasgupta, S.; Deichmann, U.; Meisner, C.; Wheeler, D. Where is the Poverty-Environment Nexus? Evidence from Cambodia, Lao PDR, and Vietnam. World Dev. 2005, 33, 617-638. [CrossRef]

17. Reardon, T.; Vosti, S.A. Links between rural poverty and the environment in developing countries: Asset categories and investment poverty. World Dev. 1995, 23, 1495-1506. [CrossRef]

18. Suich, H.; Howe, C.; Mace, G. Ecosystem services and poverty alleviation: A review of the empirical links. Ecosyst. Serv. 2015, 12, 137-147. [CrossRef] 
19. Tallis, H.; Kareiva, P.; Marvier, M.; Chang, A. An ecosystem services framework to support both practical conservation and economic development. Proc. Natl. Acad. Sci. USA 2008, 105, 9457-9464. [CrossRef] [PubMed]

20. Sjöstedt, M. Ecosystem Services and Poverty Reduction: How Do Development Practitioners Conceptualize the Linkages? Eur. J. Dev. Res. 2012, 24, 777-787. [CrossRef]

21. Horký, O. Depoliticization, instrumentalization and legitimacy of Czech development cooperation: A case of imposed altruism? Éthique et économique/Ethics and Economics 2011, 8, 120-132.

22. Opršal, Z.; Harmáček, J.; Syrovátka, M. Geography of Czech aid: Where and why Czechia promotes development? Geografie 2017, 122, 169-189.

23. Ministry of Foreign Affairs. Overseas Development Assistance Strategy of the Czech Republic for the Period 2002-2007; Government Resolution No 91/2002 of 23 January 2002; Ministry of Foreign Affairs: Prague, Czech Republic, 2002.

24. Ministry of Foreign Affairs. Development Cooperation Strategy of the Czech Republic 2010-2017; Government Resolution No 366 of 24 May 2010; Ministry of Foreign Affairs: Prague, Czech Republic, 2010.

25. Berthélemy, J.-C.; Tichit, A. Bilateral donors' aid allocation decisions-A three-dimensional panel analysis. Int. Rev. Econ. Financ. 2004, 13, 253-274. [CrossRef]

26. Harrigan, J.; Wang, C. A New Approach to the Allocation of Aid Among Developing Countries: Is the USA Different from the Rest? World Dev. 2011, 39, 1281-1293. [CrossRef]

27. Lancaster, C. Foreign Aid: Diplomacy, Development, Domestic Politics; University of Chicago Press: London, UK, 2007; ISBN 978-0-226-47045-0.

28. Riddell, R. Does Foreign Aid Really Work? Oxford University Press: Oxford, UK, 2008; ISBN 9780199544462.

29. Hicks, R.; Bradley, P.; Roberts, T.; Tierney, M. Greening Aid? Understanding the Environmental Impact of Development Assistance; Oxford University Press: Oxford, UK, 2010; ISBN 9780199213948.

30. Alesina, A.; Dollar, D. Who Gives Foreign Aid to Whom and Why? J. Econ. Growth 2000, 5, 33-63. [CrossRef]

31. Berthélemy, J.-C. Bilateral Donors' Interest vs. Recipients' Development Motives in Aid Allocation: Do All Donors Behave the Same? Rev. Dev. Econ. 2006, 10, 179-194. [CrossRef]

32. Collier, P.; Dollar, D. Aid allocation and poverty reduction. Eur. Econ. Rev. 2002, 46, 1475-1500. [CrossRef]

33. Szent-Iványi, B. Aid allocation of the emerging Central and Eastern European donors. J. Int. Relat. Dev. 2012, 15, 65-89. [CrossRef]

34. Barthel, F.; Neumayer, E.; Nunnenkamp, P.; Selaya, P. Competition for Export Markets and the Allocation of Foreign Aid: The Role of Spatial Dependence among Donor Countries. World Dev. 2014, 64, 350-365. [CrossRef]

35. Dreher, A.; Fuchs, A. Rogue aid? An empirical analysis of China's aid allocation. Can. J. Polit. Sci. Rev. Can. Sci. Polit. 2016, 48, 988-1023. [CrossRef]

36. Schraeder, P.J.; Hook, S.W.; Taylor, B. Clarifying the Foreign Aid Puzzle: A Comparison of American, Japanese, French, and Swedish Aid Flows. World Polit. 1998, 50, 294-323. [CrossRef]

37. Burnside, C.; Dollar, D. Aid, Policies, and Growth. Am. Econ. Rev. 2000, 90, 847-868. [CrossRef]

38. Easterly, W.; Levine, R.; Roodman, D. Aid, Policies, and Growth: Comment. Am. Econ. Rev. 2004, 94, 774-780. [CrossRef]

39. Younas, J. Motivation for bilateral aid allocation: Altruism or trade benefits. Eur. J. Polit. Econ. 2008, 24, 661-674. [CrossRef]

40. Harmáček, J.; Syrovátka, M.; Opršal, Z. Factors of Czech aid selection and allocation: Panel probit and tobit analysis. Polit. Ekon. 2017, 65, 179-197. [CrossRef]

41. World Bank. GDP Per Capita (Current US\$) I Data. Available online: https:/ / data.worldbank.org/indicator/ NY.GDP.PCAP.CD (accessed on 5 July 2018).

42. World Bank. Mortality Rate, Under-5 (Per 1000 Live Births) | Data. Available online: https:/ / data.worldbank. org/indicator/SH.DYN.MORT (accessed on 4 July 2018).

43. World Bank. Population, Total I Data. 2018. Available online: https://data.worldbank.org/indicator/SP.POP. TOTL (accessed on 3 July 2018).

44. Zwass, A. The Council for Mutual Economic Assistance: The Thorny Path from Political to Economic Integration, 1st ed.; Sharpe: New York, NY, USA, 1989; ISBN 978-0873324960. 
45. Ministry of Foreign Affairs. Výroční zprávy a dokumenty l Ministerstvo zahraničních věcí České republiky. 2016. Available online: https://www.mzv.cz/jnp/cz/zahranicni_vztahy/vyrocni_zpravy_a_dokumenty/ (accessed on 15 January 2018).

46. Czech Statistical Office. External Trade ICZSO. 2017. Available online: https://www.czso.cz/csu/czso/ external_trade_in_goods (accessed on 7 July 2018).

47. CEPII. CEPII-GeoDist-Presentation. 2011. Available online: http://www.cepii.fr/cepii/en/bdd_modele/ presentation.asp?id=6 (accessed on 10 July 2018).

48. Freedom House. Freedom in the World I Freedom House. 2017. Available online: https://freedomhouse. org/report-types / freedom-world (accessed on 29 June 2018).

49. OECD. OECD Statistics. GeoBook: Geographical Flows to Developing Countries. 2018. Available online: https: / / stats.oecd.org/Index.aspx (accessed on 26 June 2018).

50. Lundsgaarde, E.; Breunig, C.; Prakash, A. Instrumental Philanthropy: Trade and the Allocation of Foreign Aid. Can. J. Polit. Sci. 2010, 43, 733-761. [CrossRef]

51. Dreher, A.; Nunnenkamp, P.; Thiele, R. Are 'New' Donors Different? Comparing the Allocation of Bilateral Aid Between nonDAC and DAC Donor Countries. World Dev 2011, 39, 1950-1968. [CrossRef]

52. Hole, D.G.; Perkins, A.J.; Wilson, J.D.; Alexander, I.H.; Grice, P.V.; Evans, A.D. Does organic farming benefit biodiversity? Biol. Conserv. 2005, 122, 113-130. [CrossRef]

53. Tuomisto, H.L.; Hodge, I.D.; Riordan, P.; Macdonald, D.W. Does organic farming reduce environmental impacts?-A meta-analysis of European research. J. Environ. Manag. 2012, 112, 309-320. [CrossRef] [PubMed]

54. Dytrtová, K.; Šarapatka, B.; Opršal, Z. Does organic farming influence landscape composition? Two cases from the Czech Republic. Agroecol. Sustain. Food Syst. 2016, 40, 714-735. [CrossRef]

55. Food and Agriculture Organization. AQUASTAT Database. Available online: http://www.fao.org/nr/ water/aquastat/data/query/index.html?lang=en (accessed on 3 July 2018).

56. World Bank. Droughts, Floods, Extreme Temperatures (\% of Population, Average 1990-2009) I Data. 2018. Available online: https:/ / data.worldbank.org/indicator/EN.CLC.MDAT.ZS (accessed on 3 July 2018).

57. World Bank. CO2 Emissions (kg Per PPP \$ of GDP) I Data. 2018. Available online: https: / / data.worldbank. org/indicator/EN.ATM.CO2E.PP.GD (accessed on 27 June 2018).

58. Global Footprint Network. Open Data Platform. 2018. Available online: http://data.footprintnetwork.org/ \#/ (accessed on 21 April 2018).

59. IUCN. The IUCN Red List of Threatened Species 2018. 2018. Available online: https:/ / www.iucnredlist.org/ resources/summary-statistics (accessed on 7 June 2018).

60. World Bank. Forest Area (\% of Land Area) IData. 2018. Available online: https://data.worldbank.org/ indicator/AG.LND.FRST.ZS (accessed on 17 June 2018).

61. Yale Center for Environmental Law \& Policy. Downloads IEnvironmental Performance Index. 2018. Available online: https:/ / epi.envirocenter.yale.edu/epi-downloads (accessed on 4 July 2018).

62. Kummu, M.; Guillaume, J.H.A.; de Moel, H.; Eisner, S.; Flörke, M.; Porkka, M.; Siebert, S.; Veldkamp, T.I.E.; Ward, P.J. The world's road to water scarcity: Shortage and stress in the 20th century and pathways towards sustainability. Sci. Rep. 2016, 6, 38495. [CrossRef] [PubMed]

63. Schewe, J.; Heinke, J.; Gerten, D.; Haddeland, I.; Arnell, N.W.; Clark, D.B.; Dankers, R.; Eisner, S.; Fekete, B.M.; Colón-González, F.J.; et al. Multimodel assessment of water scarcity under climate change. Proc. Natl. Acad. Sci. USA 2014, 111, 3245-3250. [CrossRef]

64. Tarrass, F.; Benjelloun, M. The effects of water shortages on health and human development. Perspect. Public Health 2012, 132, 240-244. [CrossRef]

65. Watkins, K. Human Development Report 2006-Beyond Scarcity: Power, Poverty and the Global Water Crisis; United Nations: New York, NY, USA, 2006; ISBN 0-230-50058-7.

66. Falkenmark, M. The massive water scarcity now threatening Africa-Why isnt it being addressed? Ambio 1989, 18, 111-118.

67. Gleick, P.H. Basic Water Requirements for Human Activities: Meeting Basic Needs. Water Int. 1996, $21,83-92$. [CrossRef]

68. Jakobsen, K.T. In the Eye of the Storm-The Welfare Impacts of a Hurricane. World Dev. 2012, 40, 2578-2589. [CrossRef]

69. Rufat, S.; Tate, E.; Burton, C.G.; Maroof, A.S. Social vulnerability to floods: Review of case studies and implications for measurement. Int. J. Disaster Risk Reduct. 2015, 14, 470-486. [CrossRef] 
70. Noy, I. The macroeconomic consequences of disasters. J. Dev. Econ. 2009, 88, 221-231. [CrossRef]

71. Loayza, N.V.; Olaberría, E.; Rigolini, J.; Christiaensen, L. Natural Disasters and Growth: Going Beyond the Averages. World Dev. 2012, 40,1317-1336. [CrossRef]

72. Horký, O. The Transfer of the Central and Eastern European 'Transition Experience' to the South: Myth or Reality? Perspect. Eur. Polit. Soc. 2012, 13, 17-32. [CrossRef]

73. Szent-Iványi, B.; Végh, Z. Is transition experience enough? The donor-side effectiveness of Czech and Polish democracy aid to Georgia. Democratization 2018, 25, 614-632. [CrossRef]

74. Markandya, A.; Pedroso-Galinato, S.; Streimikiene, D. Energy intensity in transition economies: Is there convergence towards the EU average? Energy Econ. 2006, 28, 121-145. [CrossRef]

75. Cornillie, J.; Fankhauser, S. The energy intensity of transition countries. Energy Econ. 2004, 26, $283-295$. [CrossRef]

76. Rafaj, P.; Amann, M.; Siri, J.; Wuester, H. Changes in European greenhouse gas and air pollutant emissions 1960-2010: Decomposition of determining factors. Clim. Chang. 2014, 124, 477-504. [CrossRef]

77. Merino-Saum, A.; Baldi, M.G.; Gunderson, I.; Oberle, B. Articulating natural resources and sustainable development goals through green economy indicators: A systematic analysis. Resour. Conserv. Recycl. 2018, 139, 90-103. [CrossRef]

78. Koide, R.; Akenji, L. Assessment of Policy Integration of Sustainable Consumption and Production into National Policies. Resources 2017, 6, 48. [CrossRef]

79. Janoušková, S.; Hák, T.; Moldan, B. Global SDGs Assessments: Helping or Confusing Indicators? Sustainability 2018, 10, 1540. [CrossRef]

80. Wackernagel, M.; Onisto, L.; Bello, P.; Callejas Linares, A.; Susana López Falfán, I.; Méndez García, J.; Isabel Suárez Guerrero, A.; Guadalupe Suárez Guerrero, M. National natural capital accounting with the ecological footprint concept. Ecol. Econ. 1999, 29, 375-390. [CrossRef]

81. Fiala, N. Measuring sustainability: Why the ecological footprint is bad economics and bad environmental science. Ecol. Econ. 2008, 67, 519-525. [CrossRef]

82. Čuček, L.; Klemeš, J.J.; Kravanja, Z. A Review of Footprint analysis tools for monitoring impacts on sustainability. J. Clean. Prod. 2012, 34, 9-20. [CrossRef]

83. Chapin, F.S., III; Zavaleta, E.S.; Eviner, V.T.; Naylor, R.L.; Vitousek, P.M.; Reynolds, H.L.; Hooper, D.U.; Lavorel, S.; Sala, O.E.; Hobbie, S.E.; et al. Consequences of changing biodiversity. Nature 2000, 405, $234-242$. [CrossRef]

84. Butchart, S.H.M.; Walpole, M.; Collen, B.; van Strien, A.; Scharlemann, J.P.W.; Almond, R.E.A.; Baillie, J.E.M.; Bomhard, B.; Brown, C.; Bruno, J.; et al. Global Biodiversity: Indicators of Recent Declines. Science 2010, 328, 1164-1168. [CrossRef]

85. Adams, W.; Hutton, J. People, Parks and Poverty: Political Ecology and Biodiversity Conservation. Conserv. Soc. 2007, 5, 147-183.

86. Opršal, Z.; Harmáček, J.; Pavlík, P.; Machar, I. What factors can influence the expansion of protected areas around the world in the context of international environmental and development goals? Probl. Ekorozwoju 2018, 13, 145-157.

87. Butchart, S.H.M.; Akcakaya, H.R.; Kennedy, E.; Hilton-Taylor, C. Biodiversity Indicators Based on Trends in Conservation Status: Strengths of the IUCN Red List Index. Conserv. Biol. 2006, 20, 579-581. [CrossRef]

88. Butchart, S.H.M.; Resit Akçakaya, H.; Chanson, J.; Baillie, J.E.M.; Collen, B.; Quader, S.; Turner, W.R.; Amin, R.; Stuart, S.N.; Hilton-Taylor, C. Improvements to the Red List Index. PLoS ONE 2007, 2, e140. [CrossRef]

89. Alroy, J. Effects of habitat disturbance on tropical forest biodiversity. Proc. Natl. Acad. Sci. USA 2017, 114, 6056-6061. [CrossRef]

90. Rosa, I.M.D.; Smith, M.J.; Wearn, O.R.; Purves, D.; Ewers, R.M. The Environmental Legacy of Modern Tropical Deforestation. Curr. Biol. 2016, 26, 2161-2166. [CrossRef]

91. Sunderlin, W.D.; Dewi, S.; Puntodewo, A.; Müller, D.; Angelsen, A.; Epprecht, M. Why Forests Are Important for Global Poverty Alleviation: A Spatial Explanation. Ecol. Soc. 2008, 13, 24. [CrossRef]

92. Opršal, Z.; Harmáček, J.; Syrovátka, M. The allocation of Czech foreign aid in Sub-Saharan Africa: The influence of historical relationships. Int. J. Econ. Policy Emerg. Econ. 2016, 9, 325-343. [CrossRef]

93. Hansen, M.C.; Stehman, S.V.; Potapov, P.V. Quantification of global gross forest cover loss. Proc. Natl. Acad. Sci. USA 2010, 107, 8650-8655. [CrossRef] 
94. Acemoglu, D.; Johnson, S.; Robinson, J.A. The Colonial Origins of Comparative Development: An Empirical Investigation. Am. Econ. Rev. 2001, 91, 1369-1401. [CrossRef]

95. Rodrik, D.; Subramanian, A.; Trebbi, F. Institutions Rule: The Primacy of Institutions Over Geography and Integration in Economic Development. J. Econ. Growth 2004, 9, 131-165. [CrossRef]

96. Canavire, G.; Nunnenkamp, P.; Thiele, R.; Triveño, L. Assessing the Allocation of Aid. Indian Econ. J. 2006, 54, 26-51. [CrossRef]

97. Gallego-Alvarez, I.; Vicente-Galindo, M.; Galindo-Villardón, M.; Rodríguez-Rosa, M. Environmental Performance in Countries Worldwide: Determinant Factors and Multivariate Analysis. Sustainability 2014, 6, 7807-7832. [CrossRef]

98. Worker, J.; De Silva, L. The Environmental Democracy Index; World Resource Institute: Washington, DC, USA, 2002.

99. Spooner, M. Decline in Energy Intensity in the Czech Republic: Due to Structural Change or Energy Efficiency Improvement? Economic Briefs 7; Publications Office of the European Union: Luxembourg, 2016; ISBN 978-92-79-54467-5.

100. Adams, W.M.; Aveling, R.; Brockington, D.; Dickson, B.; Elliott, J.; Hutton, J.; Roe, D.; Vira, B.; Wolmer, W. Biodiversity conservation and the eradication of poverty. Science 2004, 306, 1146-1149. [CrossRef]

101. West, P.; Igoe, J.; Brockington, D. Parks and Peoples: The Social Impact of Protected Areas. Annu. Rev. Anthropol. 2006, 35, 1317-1336. [CrossRef]

102. Cernea, M.M.; Schmidt-Soltau, K. Poverty Risks and National Parks: Policy Issues in Conservation and Resettlement. World Dev. 2006, 34, 1808-1830. [CrossRef]

103. DeFries, R.; Hansen, A.; Turner, B.L.; Reid, R.; Liu, J. Land Use Change Around Protected Areas: Management to Balance Human Needs tnd Ecological Function. Ecol. Appl. 2007, 17, 1031-1038. [CrossRef]

104. Brockington, D.; Wilkie, D. Protected areas and poverty. Philos. Trans. R. Soc. Lond. B. Biol. Sci. 2015, 370, 20140271. [CrossRef]

(C) 2019 by the authors. Licensee MDPI, Basel, Switzerland. This article is an open access article distributed under the terms and conditions of the Creative Commons Attribution (CC BY) license (http:/ / creativecommons.org/licenses/by/4.0/). 